\title{
Relationship between Commodity Prices and Exchange Rate in Light of Global Financial Crisis: Evidence from Australia
}

\author{
Omar K. M. R. Bashar and Sarkar Humayun Kabir
}

\begin{abstract}
This study seeks to identify major factors behind recent fluctuations in Australian dollar. Using quarterly data for over 30 years and cointegration and error correction models, we found that in the long run exchange rate is determined by commodity prices, interest rate and other factors such as Global Financial Crisis. We found two-way Granger causality between exchange rate and commodity prices, but one-way Granger causality from Global Financial Crisis to commodity prices. The implications of our findings is that by providing substantial incentives to Australian producers, the policy makers in Australia can ensure competitive commodity prices and exchange rate. Portfolio managers could also benefit from our findings knowing the mechanism of Global Financial Crisis impacting Australian dollar.
\end{abstract}

Index Terms-Commodity prices, exchange rate, global financial crisis, cointegration.

\section{INTRODUCTION}

The Global Financial Crisis (GFC) of 2007-2008, which originated from the burst of US housing market owing mainly to easier access to subprime mortgages and plummet of real estate pricing, threatened collapse of the global financial system. Australia is one of the few countries that have been able to maintain a stable economy (with average GDP growth rate of 2.63 percent from 2007-2011, World Bank 2013[1]) during GFC. Interestingly the Australian dollar depicted a strong value against the US dollar during post-GFC period, which again began to decline lately. Naturally the question arises: are fluctuations in Australian nominal exchange rate due to changes in its commodity prices? Or they are caused by the GFC which many countries still reeling from?

There have been a few studies examining the relationship between commodity prices and exchange rate. Some studies focused on explaining changes in commodity prices due to changes in exchange rates. Chen at al. (2008) [2] using Granger causality tests through multivariate regression found commodity currency exchange rates robustly predicting global commodity prices, whereas weak predicting power was found for commodity prices forecasting exchange rates. Simpson (2002) [3] using ordinary least squares method studied the relationship between commodity prices and Australian dollar and reported greater explanatory power of commodity prices in

Manuscript received June 10, 2013; revised August 1, 2013

Omar K. M. R. Bashar is with Swinburne University of Technology, Australia (e-mail: obashar@swin.edu.au).

Sarkar Humayun Kabir is with The Global University of Islamic Finance (INCEIF), Malaysia. explaining exchange rate fluctuations. Arezki et al. (2012) [4] through cointegration tests and vector error correction models established causality running from South African Rand to gold price volatility before the capital account was liberalized; the direction of causality reverses after capital account liberalization. Edwards (1985) [5] studying the relationship between exchange rate and world coffee prices reported that coffee price changes had been negatively related to devaluation of Colombian currency. Similar findings were reported in other studies. Thus, the existing literature on the relationship between commodity prices and exchange rates has been mixed. Unlike those studies we include GFC as a possible factor (e.g. speculation) impacting on the relationship between commodity prices and exchange rates, and attempt to see whether there is any short-run causality and long-run relationship between the two in case of Australia.

The remaining part of the study is organized as follows: section two discusses data and methodology; section three describes findings with interpretation and finally, the study wraps up with concluding remarks and policy implications in section four.

\section{DATA AND METHODOLOGY}

\section{A. The Model}

Theoretically nominal exchange rate is positively related to commodity prices and interest rates; on the other hand, Global Financial Crisis through impacting purchasing power of Australia's major trading partners could impact Australian currency (nominal exchange rate) negatively. We consider a VAR model comprising of these variables and see whether we could establish a link among them.

\section{B. Sources of Data and Variables}

We use quarterly data from 1982Q3 to 2013Q2. The period covers 2007-2008 Global Financial Crisis as well. Data sources include the Australian Bureau of Statistics and Reserve Bank of Australia. Variables of the study are shown in Table I.

TABLE I: VARIABLES USED IN THE STUDY

\begin{tabular}{ll}
\hline Variable & Explanation \\
\hline LNER & Logarithmic value of US\$/AU\$ Exchange Rate (ER) \\
LNCP & Logarithmic value of Commodity Prices (CP) index \\
R & Nominal Interest Rate \\
D & $\begin{array}{l}\text { Dummy variable as proxy for 2007-2008 Global } \\
\text { Financial Crisis, with 2007Q1 to 2012Q2 being 1, } \\
\text { otherwise 0 }\end{array}$ \\
\hline
\end{tabular}


This study employs the Johansen multivariate cointegration approach to test if there is any cointegration among the variables in our model. We also conduct Granger causality tests to see short-run dynamics among the variables.

\section{RESULTS}

We applied both Augmented Dickey Fuller (ADF) [6], [7] and Phillips Perron (PP) [8] unit root tests with intercept and intercept and linear trend to check the stationarity of the variables. Table II summarizes the unit root test results.

TABLE II: UNIT ROOT TESTS FOR STATIONARITY

\begin{tabular}{|c|c|c|c|c|c|c|}
\hline \multirow[t]{2}{*}{ Variables } & \multirow[t]{2}{*}{$\begin{array}{c}\text { Level/ } \\
\text { First Diff }\end{array}$} & \multicolumn{2}{|c|}{$\begin{array}{l}\text { Aug. Dickey-Fuller } \\
\text { (ADF) Test Statistic }\end{array}$} & \multicolumn{2}{|c|}{$\begin{array}{c}\text { Phillips-Perron (PP) } \\
\text { Test Statistic }\end{array}$} & \multirow[t]{2}{*}{ Conclusion } \\
\hline & & Without Trend & $\begin{array}{c}\text { With } \\
\text { Trend } \\
\end{array}$ & $\begin{array}{c}\text { Without } \\
\text { Trend }\end{array}$ & $\begin{array}{l}\text { With } \\
\text { Trend }\end{array}$ & \\
\hline LNER & $\begin{array}{c}\text { Level } \\
\text { First } \\
\text { Difference }\end{array}$ & $\begin{array}{c}-1.86(0) \\
-11.13 *(0)\end{array}$ & $\begin{array}{c}-2.11(0) \\
-11.29 *(0)\end{array}$ & $\begin{array}{l}-1.96 \\
-11.14 *\end{array}$ & $\begin{array}{c}-2.12 \\
-11.40^{*}\end{array}$ & $\mathrm{I}(1)$ \\
\hline LNCP & $\begin{array}{c}\text { Level } \\
\text { First } \\
\text { Difference }\end{array}$ & $\begin{array}{l}-0.21(1) \\
-6.72 *(0)\end{array}$ & $\begin{array}{l}-1.68(1) \\
-6.84 *(0)\end{array}$ & $\begin{array}{l}0.28 \\
-6.52 *\end{array}$ & $\begin{array}{l}-1.29 \\
-6.51 *\end{array}$ & $\mathrm{I}(1)$ \\
\hline $\mathrm{R}$ & $\begin{array}{c}\text { Level } \\
\text { First } \\
\text { Difference }\end{array}$ & $\begin{array}{l}-1.17(8) \\
-4.90 *(7)\end{array}$ & $\begin{array}{l}-2.04(8) \\
-4.88 *(7)\end{array}$ & $\begin{array}{l}-2.15 \\
-10.10^{*}\end{array}$ & $\begin{array}{l}-2.96 \\
-10.05^{*}\end{array}$ & $\mathrm{I}(1)$ \\
\hline
\end{tabular}

Notes: i) In ADF tests, optimum lag lengths, shown in parentheses in the test statistic column, have been determined using Schwartz Bayesian Criterion (SBC). ii) In PP tests, Bartlett kernel (default) spectral estimation method and Newey-West bandwidth (automatic selection) have been used. iii) Conclusion about the order of integration of a particular variable is based on the test that did not include the trend in the test equation. Test statistics "with trend" have been shown for the purpose of reporting only. iv) * denotes significant at 5 percent level. Mackinnon (1996) [9] one-sided p-values have been used for this purpose.

TABLE III: JOHANSEN-JUSELIUS MAXIMUM LIKELIHOOD COUNTERACTION TESTS

\begin{tabular}{ccccc}
\hline Null Hypothesis & $\begin{array}{c}\text { Trace Test } \\
\text { Alternative } \\
\text { Hypothesis }\end{array}$ & $\begin{array}{c}\text { Test } \\
\text { Statistic }\end{array}$ & $\begin{array}{c}\text { Null } \\
\text { Hypothesis }\end{array}$ & $\begin{array}{c}\text { Maximum Eigenvalue Test } \\
\text { Alternative } \\
\text { Hypothesis }\end{array}$ \\
\hline$r=0$ & $r>0$ & 43.19 & $r=0$ & $r=1$ \\
Statistic
\end{tabular}

Notes: i) $r$ refers to number of counteracting equations. ii) The test has been conducted assuming linear deterministic trend. iii) $*$ denotes rejection of null hypothesis of no cointegration at 5 percent significance level. MacKinnon-Haug-Michelis (1999) [10] p-values have been used for this purpose.

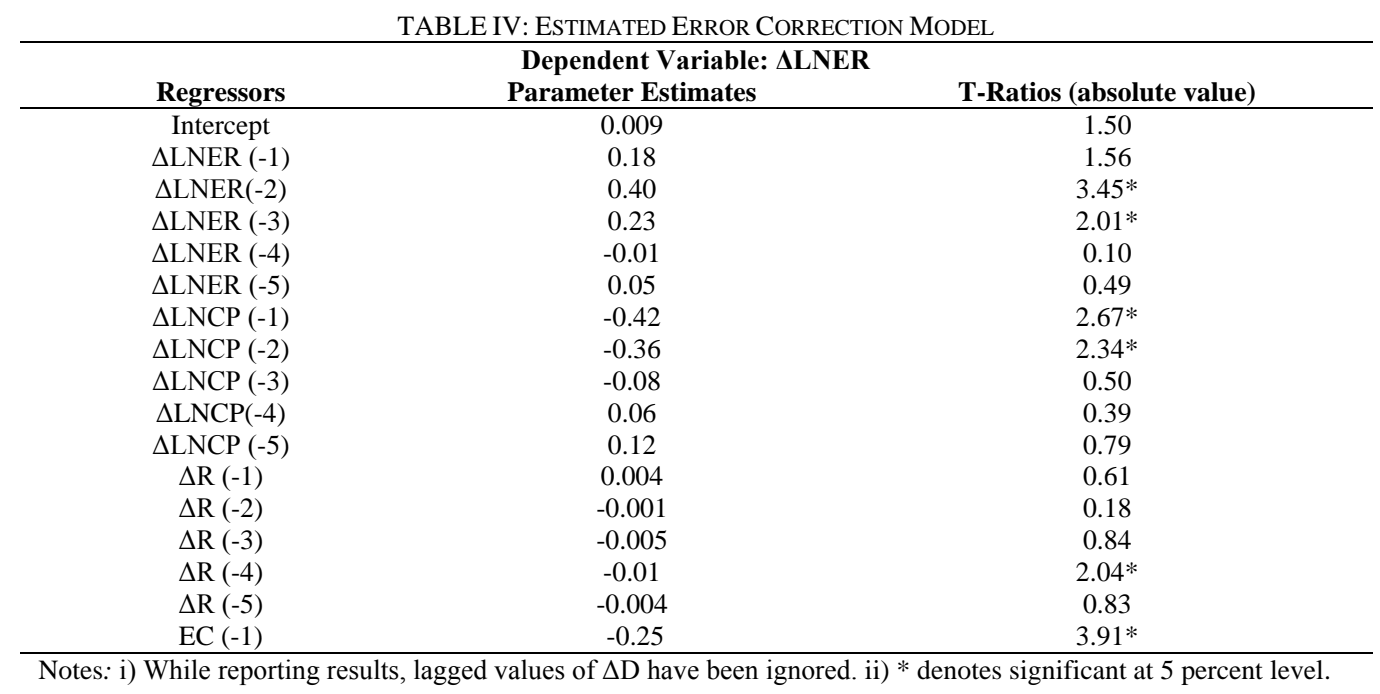

As all variables in the model are found to be I (1), we conduct Johansen-Juselius cointegration analysis [11-12]. Based on LR, FPE and AIC lag order selection criteria, we specify the relevant order of lags $p=6$ of the VAR model (implies a lag length of 5 in VEC model) before conducting cointegration tests which results have been shown in Table
III.

At 5 percent significance level, the trace test indicates no cointegrating equations while the maximum eigenvalue test indicates 1 cointegrating equation among the variables. As the maximum eigenvalue test is usually preferred for trying to pin down the number of cointegrating vectors (Enders, 
2004; p 354) [13], we conclude that there is 1 cointegrating equation among the variables based on this test. When normalized for a unit coefficient on LNER, the cointegrating regression of nominal exchange rate can be given as follows (standard errors in parentheses):

$$
\begin{aligned}
L N E R= & -2.6+0.64 L N C P+0.02 R-0.35 D \\
& (0.10) \quad(0.004) \quad(0.11)
\end{aligned}
$$

In the estimated model above, none of the coefficients of explanatory variables of nominal exchange rate is found to be greater than unity, indicating low responsiveness of exchange rate to changes in these variables.

The coefficient estimates of the variables $C P, R$ and $D$ in the equilibrium relation are significant at 5 percent level and have the expected signs. Thus, commodity prices, interest rate and Global Financial Crisis are found to be the main determinants of exchange rate.

We estimate the error correction model in order to determine the dynamic behavior of nominal exchange rate, results of which are displayed in Table IV.

The estimated coefficient of the error term $(-0.25)$ has been found statistically significant at 5 percent level with appropriate (negative) sign. This suggests that the system corrects its previous period's disequilibrium by 25 percent a quarter.

The cointegrating relationship among the variables suggests existence of Granger causality in at least one direction, but it does not indicate the direction of temporal causality between the variables. In order to determine the direction of causality, we run the Granger causality test within the ECM (error correction model), which results have been shown in Table V.

TABLE V: GRANGER CAUSALITY TEST

\begin{tabular}{ccccc}
\hline & & Dependent Variable & & $\Delta \mathrm{D}$ \\
\hline & $\Delta \mathrm{LNER}$ & $\Delta \mathrm{LNCP}$ & $\Delta \mathrm{R}$ & 6.48 \\
$\Delta \mathrm{LNER}$ & & $20.69^{*}$ & 4.49 & $(0.37)$ \\
& & $(0.002)$ & $(0.61)$ & 10.46 \\
$\Delta \mathrm{LNCP}$ & $24.84^{*}$ & & 9.19 & $(0.11)$ \\
& $(0.0004)$ & & $(0.16)$ & 1.94 \\
$\Delta \mathrm{R}$ & 7.04 & 1.49 & & $(0.93)$ \\
& $(0.32)$ & $(0.96)$ & & \\
$\Delta \mathrm{D}$ & 11.22 & $29.17 *$ & 2.48 & $(0.87)$ \\
\hline
\end{tabular}

Notes: i) A VAR lag length of 6 has been used in the Granger causality test. ii) Corresponding probabilities have been shown in parentheses.

iii) * denotes significant at 5 percent level. It indicates causal relationship.

The Granger causality test results indicate unidirectional causality from Global Financial Crisis to commodity prices. Besides, the results indicate a two-way relationship between commodity prices and exchange rate. We found no causal relationship among other variables.

The above results are plausible. Global Financial Crisis impacts commodity prices; and commodity prices and exchange rates are linked. For instance, higher Australian commodity price implies foreigners buying more Australian dollar to pay for Australian goods and services. On the other hand, higher value of Australian dollar may force foreign consumers to reduce demand for non-essential Australian goods and services.

Finally we perform diagnostic tests using correlogram of the residuals, which indicate presence of no serial correlation at 5 percent significance level. Diagnostic test results have been shown in Appendix.

\section{CONCLUSION}

This study investigated whether Australian nominal exchange rate is determined by major commodity prices, interest rate and other factors (such as Global Financial Crisis). Using cointegration and error correction models on quarterly data for the period 1982Q3 to 2013Q2, we found coefficients of commodity prices and interest rate to be positive and significant, implying positive impact of these variables on Australia's exchange rate in the long run. On the other hand, we found coefficient of dummy variable to be negative and significant, implying negative impact of Global Financial Crisis on exchange rate. The vector error correction results indicate that in the short run exchange rate is influenced by lagged exchange rates (quarters 2 and 3), commodity prices (quarters 1 and 2) and interest rate (quarter 4). The coefficient of error correction term is found to be negative (-0.25) and significant, implying that a longrun relationship exists among the variables in the model. Based on Granger causality tests, we found unidirectional causality from Global Financial Crisis to commodity prices, and two-way causality between commodity prices and exchange rate.

Our findings confirm the theoretical concept that exchange rate is determined by commodity prices, interest rate and other factors, such as speculative motive (as proxied by Global Financial Crisis or dummy variable). They have significant implications for both policy makers and portfolio managers. From policy point of view, maintaining weaker exchange rate would be conducive to increasing exports since exportable items get cheaper to importing economies and thus achieving long run growth, and vice-versa. However, exchange rate could be stronger with increase in export of commodities by keeping the commodity prices lower. Australia though industrialized economy, produces and exports a greater number of primary and secondary commodities and therefore, it is important to keep commodity prices lower. This action would be helpful 
for raising Australian exports and reserves necessary for fostering long run economic growth. One way of doing this is to ensure increased efficiency of Australian producers. Policy makers in Australia may try to achieve this goal by providing more incentives to local producers for promoting innovation. Furthermore, rising commodity prices may lead to higher inflation and interest rate within Australian economy, which would have detrimental effect in Australian equity market. Notwithstanding, rising commodity prices would be beneficial to Australian economy only when the commodity is price inelastic.

These findings may also help the portfolio managers, who would be willing to include major commodities into their investment portfolios since commodities in general can be used as hedging instruments against unexpected inflation. In addition to hedging inflation, commodities may help portfolio managers in insulating their losses from equities, particularly during financial turbulence period, such as 2007-2008 Global Financial Crisis.

\section{APPENDIX}

Autocorrelations w ith 2 Std.Err. Bounds
Cor(LNER,LNER(-i))

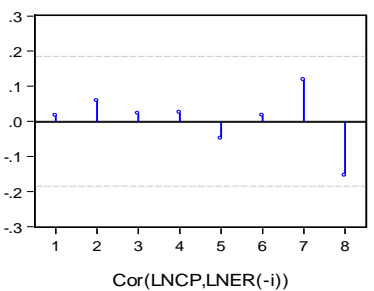

$\operatorname{Cor}($ LNCP,LNER(-i))

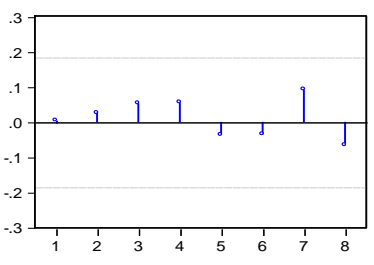

$\operatorname{Cor}(R, \operatorname{LNER}(-\mathrm{i}))$

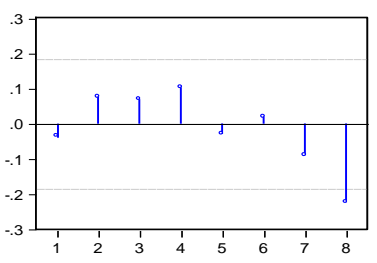

Cor(D01,LNER(-i))

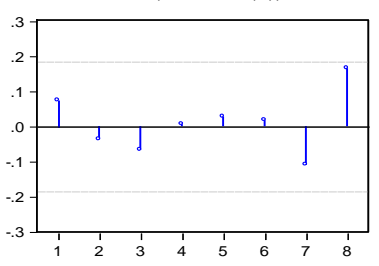

Cor(LNER,LNCP(-i))
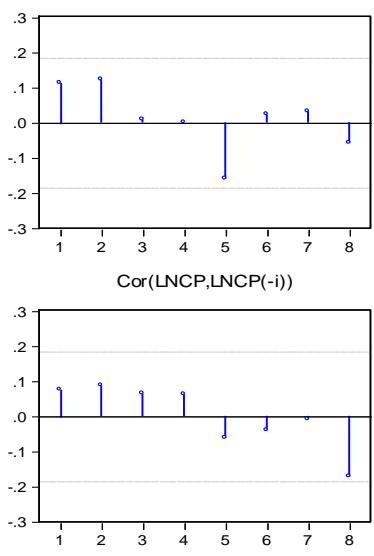

$\operatorname{Cor}(\mathrm{R}, \mathrm{LNCP}(-\mathrm{i}))$

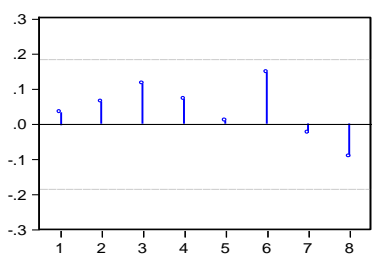

Cor(D01,LNCP(-i))

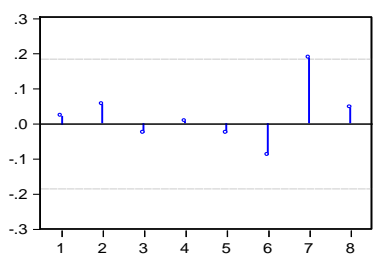

$\operatorname{Cor}(\operatorname{LNCP}, \operatorname{LNCP}(-\mathrm{i}))$

\section{REFERENCES}

[1] World Development Indicators Online, World Bank 2013.

[2] Y. C. Chen, K. Rogoff, and B. Rossi, Can Exchange Rates Forecast Commodity Prices? Working Paper No. 13901, National Bureau of Economic Research, 2008.

[3] J. L. Simpson. (2002). The Relationship Between Commodity Prices and the Australian Dollar. EFMA 2002 London Meetings. [Online]. Available http://ssrn.com/abstract=314872 http://dx.doi.org/10.2139/ssrn.314872

[4] R. Arezki, E. Dumitrescu, A. Freytag, and M. Quintyn, Commodity Prices and Exchange Rate Volatility: Lessons from South Africa's Capital Account Liberalization, Working Paper, no. WP/12/168, International Monetary Fund, 2012.

[5] S. Edwards, Commodity Export Prices and the Real Exchange Rate in Developing Countries: Coffee in Colombia, Working Paper, no. 1570, National Bureau of Economic Research, 1985.

[6] D. A. Dickey and W. A. Fuller, "Distribution of the estimators for autoregressive time series with a unit root," Journal of the American Statistical Association, vol. 74, pp. 427-431, 1979.

[7] D. A. Dickey and W. A. Fuller, "Likelihood ratio statistics for autoregressive time series with a unit root," Econometrica, vol. 49 , pp. 1057-1072, 1981
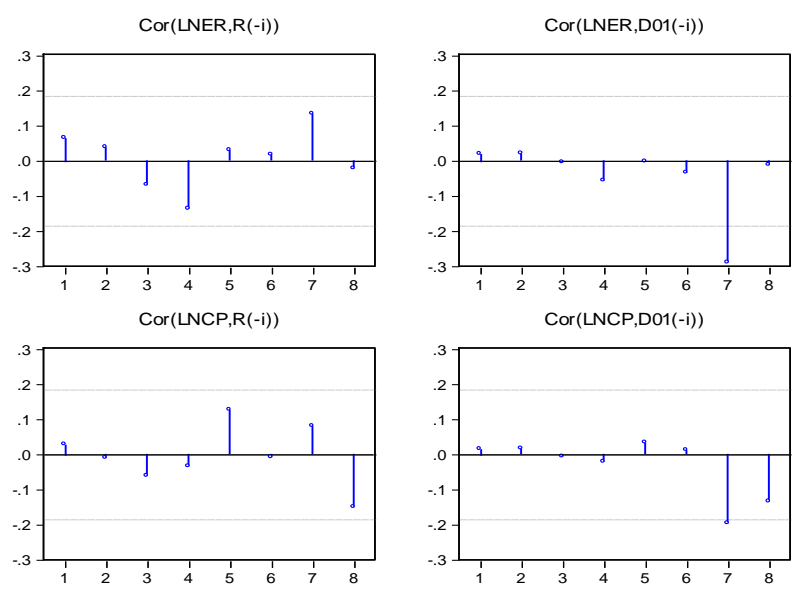

$\operatorname{Cor}(R, R(-i))$

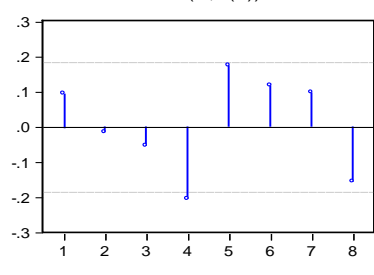

$\operatorname{Cor}(\mathrm{R}, \mathrm{D} 01(-\mathrm{i}))$

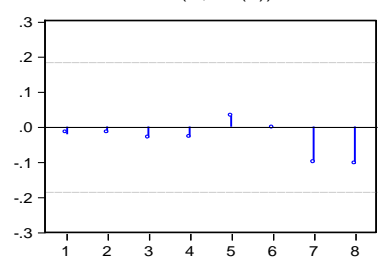

$\operatorname{Cor}(\mathrm{D} 01, \mathrm{R}(-\mathrm{i}))$

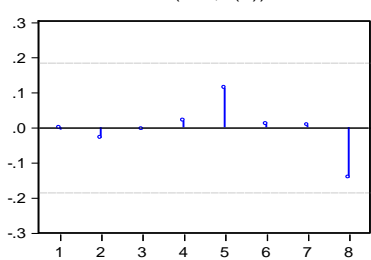

Cor(D01,D01(-i)

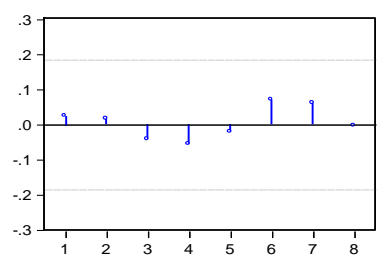

[8] P. C. B. Phillips and P. Perron, "Testing for a unit root in time series regression," Biometrica, vol. 75, pp. 335-46, 1988.

[9] J. G. MacKinnon, "Numerical distribution functions for unit root and cointegration tests," Journal of Applied Econometrics, vol. 11, pp. 601-618, 1996.

[10] J. G. MacKinnon, A. A. Haug, and L. Michelis, "Numerical distribution functions of likelihood ratio tests for cointegration," Journal of Applied Econometrics, vol. 14, pp. 563-577, 1999.

[11] S. Johansen, "Statistical analysis of cointegration vectors," Journal of Economic Dynamics and Control, vol. 12, pp. 231-254, 1988.

[12] S. Johansen and K. Juselius, "Maximum likelihood estimation and inference on cointegration with applications to the demand for money," Oxford Bulletin of Economics and Statistics, vol. 52, pp. 169-210, 1990.

[13] W. Enders, Applied Econometric Time Series, 2004, John Wiley \& Sons, Inc.

Omar K. M. R. Bashar is a lecturer in Accounting and Finance at the Faculty of Business and Enterprise in Swinburne University of Technology, Australia. His research interests include open economy macroeconomics, economic growth and development, international trade and finance, and Islamic finance. Omar published articles in Studies in Economics and 
Finance, The Journal of Developing Areas, International Journal of Trade and Global Markets, The Bangladesh Development Studies, Malaysian Journal of Economic Studies, Bank Parikrama, Journal of Islamic Banking and Finance, and The AIUB Journal of Business and Economics

Sarkar Humayun Kabir is an assistant professor of Finance at the American International University - Bangladesh (AIUB). He has been pursuing $\mathrm{PhD}$ degree in Islamic Finance at the Global University of Islamic Finance (INCEIF), Kuala Lumpur, Malaysia. He also holds Chartered Islamic Finance Professional (CIFP) degree from the same school. Before
CIFP, he completed two master degrees in finance and banking, one from the KDI School of Public Policy and Management, Seoul, Korea and another from the University of Rajshahi, Bangladesh. His research interests include Islamic and mainstream capital markets, Islamic and mainstream banking, financial institutions management and international finance. He has published in referred journals such as Journal of Developing Areas, Australian Journal of Basic and Applied Sciences, Journal of Savings and Development, Studies in Economics and Finance, The Global Journal of Finance and Economics, Bank Parikkrama, and Dhaka University Business Studies Journal. 